\title{
Vigor testings for evaluating the physiological quality of chia seeds
}

\section{Testes de vigor para avaliar a qualidade fisiológica de sementes de chia}

\author{
Fernanda Brito Cardoso ${ }^{1}$; Carlos Henrique Queiroz Rego²; Izabela Cristina \\ de Oliveira²; Alan Mario Zuffo ${ }^{3 *}$; Ana Carina da Silva Cândidoº \\ Charline Zaratin Alves ${ }^{3}$
}

\begin{abstract}
Chia (Salvia hispanica L.) is a plant native to central and western Mexico and northern Guatemala belonging to the Lamiaceae family, well known for its seeds containing antioxidants, dietary fibers, and $\alpha$-linolenic acid, which helps to prevent different diseases, such as diabetes, obesity, cancer and Alzheimer. In Brazil, there is not much information about the crop, mainly about the physiological quality of its seeds. Therefore, the objective was to establish vigor testing methods to evaluate the physiological quality of chia seeds. Five seed lots were used, in which germination tests, seedling emergence, emergence velocity index and variations in the electrical conductivity test were carried out. The volume of distilled water was 25 and $50 \mathrm{~mL}$, the number of seeds was 50 and 100 , the temperature was 20,25 and $30^{\circ} \mathrm{C}$, the soaking period was $1,2,4,6,12,18$ and 24 hours and variations in there was accelerated aging test by the traditional method and saturated $\mathrm{NaCl}$ solution, being periods of aging as 24, 48, 72 and 96 hours and temperatures of 38,41 and $44{ }^{\circ} \mathrm{C}$. It is concluded that both the electrical conductivity test and the accelerated aging test are efficient in evaluating the physiological quality of chia seeds. The electrical conductivity test must be performed with 100 seeds in $50 \mathrm{~mL}$ of distilled water, for four hours soaking at 25 or $30^{\circ} \mathrm{C}$; and the accelerated aging test should be performed at $44^{\circ} \mathrm{C}$ for 24 hours by the traditional method or $41{ }^{\circ} \mathrm{C}$ for 24 hours using saturated $\mathrm{NaCl}$ solution.
\end{abstract}

Key words: Accelerated aging. Electric conductivity. Quality control. Salvia hispanica.

\section{Resumo}

Pertencente à família das Lamiáceas, a chia (Salvia hispanica L.) é uma planta originária do centro-oeste do México e norte da Guatemala, muito conhecida por suas sementes conterem antioxidantes, fibras dietéticas e ácido $\alpha$-linolênico, que auxilia na prevenção de várias doenças, como diabetes, obesidade, câncer e Alzheimer. No Brasil, não há muitas informações a respeito da cultura, principalmente sobre qualidade fisiológica de sementes. Sendo assim, o objetivo foi estabelecer metodologia de testes de vigor para avaliar a qualidade fisiológica de sementes de chia. Foram utilizados cinco lotes de sementes, nos quais foram realizados os testes de germinação, emergência de plântulas, índice de velocidade de emergência e variações no teste de condutividade elétrica, sendo volume de água destilada: 25 e 50 mL, quantidade de sementes: 50 e 100, temperatura: 20,25 e $30^{\circ} \mathrm{C}$ e período de embebição: $1,2,4,6$,

${ }^{1}$ M.e, em Agronomia, Universidade Federal de Mato Grosso do Sul, UFMS, Campus Chapadão do Sul, Chapadão do Sul, MS, Brasil. E-mail: fernandabcardoso@hotmail.com

2 Eng $^{\text {os }}$ Agr $^{0 s}$, UFMS, Campus Chapadão do Sul, Chapadão do Sul, MS, Brasil. E-mail: carlosqueirozagro@gmail.com; izabelamarangon@gmail.com

3 Profs., UFMS, Campus Chapadão do Sul, Chapadão do Sul, MS, Brasil. E-mail: alan_zuffo@hotmail.com; ana.candido@ufms. br; charline.alves@ufms.br

* Author for correspondence 
12,18 e 24 horas e variações no teste de envelhecimento acelerado pelo método tradicional e solução saturada de $\mathrm{NaCl}$, sendo períodos de envelhecimento: 24, 48, 72 e 96 horas e temperaturas: 38 , 41 e 44 ${ }^{\circ} \mathrm{C}$. Conclui-se que tanto o teste de condutividade elétrica quanto o de envelhecimento acelerado são eficientes na avaliação da qualidade fisiológica de sementes de chia. O teste de condutividade elétrica deve ser realizado com 100 sementes em $50 \mathrm{~mL}$ de água destilada, pelo período de quatro horas de embebição, à 25 ou $30^{\circ} \mathrm{C}$; e o teste de envelhecimento acelerado deve ser realizado à $44{ }^{\circ} \mathrm{C}$ por 24 horas pelo método tradicional ou $41^{\circ} \mathrm{C}$ por 24 horas utilizando solução saturada de $\mathrm{NaCl}$.

Palavras-chave: Salvia hispanica. Controle de qualidade. Envelhecimento acelerado. Condutividade elétrica.

\section{Introduction}

Commonly known as chia, Salvia hispanica L. is a seed rich in compounds beneficial to human health, and its information is concentrated in research related to food (MIGLIAVACCA et al., 2014). However, little is known about this crop and, due to the increase of commercial areas, there is a need for information, mainly about the physiological quality of seeds.

The use of vigor testing is important because e they identify the advances of the deterioration in seeds, allowing the differentiation of lots with similar germinative rate. Several vigor testings can be used, however, there is no standardized and recommended method for all species, since each one has its particularity (MENDONÇA et al., 2008).

Among the several known tests, the electrical conductivity has the objective of evaluating the process of seed deterioration due to loss of physical integrity of the cell membranes. It is a fast and highreliability test, which allows results in less time compared to other vigor tests, such as emergency. The electrical conductivity test is done in 24 hours, but studies have been carried out to reduce this period, maintaining its reliability (VIEIRA; KRZYZANOWSKI, 1999).

Effective results for the distinction of vigor seed lots with the reduced time electrical conductivity test were obtained by Vidigal et al. (2008) with pepper seeds, using $25 \mathrm{~mL}$ for 50 seeds at $25{ }^{\circ} \mathrm{C}$, after one hour of imbibition. Alves and Sá (2009) using arugula seeds found that using $50 \mathrm{~mL}$ for 50 seeds at $25^{\circ} \mathrm{C}$, it was possible to obtain an efficient result after four hours of imbibition. In sesame seeds, Kulczynski et al. (2014) found that it is possible to separate lots from two hours soaking in deionized water when using $75 \mathrm{~mL}$ for 25 seeds at $25^{\circ} \mathrm{C}$. Alves et al. (2012) obtained similar results in eggplant seeds in the four-hour soaking period when $50 \mathrm{~mL}$ for 25 seeds were used at $30^{\circ} \mathrm{C}$. Pereira et al. (2008) observed that in basil seeds, the electrical conductivity test can be reduced from 24 to 16 hours of imbibition.

Another usual test is the test of accelerated aging, recommended for evaluating the vigor of the seeds of several cultivated species, being able to provide information with a high degree of reliability (HAMPTON; TEKRONY, 1995). This test evaluates seed germination after being subjected to stress due to temperature rise and relative air humidity for a certain period of time (ROSSETTO; MARCOS FILHO, 1995), considerably increasing the rate of deterioration (NAKAGAWA, 1999). Lots with high vigor deteriorate more slowly and lots with low vigor have greater drop in viability after being exposed to situations like these. Using the traditional methodology (just water under the seeds) Barbosa et al. (2011) observed satisfactory results in lettuce seeds, using the combination of 41 ${ }^{\circ} \mathrm{C}$ for 72 hours. Souza et al. (2009) also observed positive results of this test on black oat seeds, using $40{ }^{\circ} \mathrm{C}$ for 24 hours of seed exposure.

The electrical conductivity test can also be performed with saturated sodium chloride $(\mathrm{NaCl})$ solution, reducing the relative humidity of the environment to $76 \%$, demonstrating efficiency in the control of water absorption by seeds and in 
the vigor evaluation (JIANHUA; MCDONALD, 1996). Alves and Sá (2012) verified benefits of the saturated solution compared to the traditional procedure in arugula seeds at $41{ }^{\circ} \mathrm{C}$ for 72 and 96 hours of exposure period. Similar results were found by Lopes et al. (2009) and Radke et al. (2016) in ryegrass and coriander seeds, respectively, at 41 ${ }^{\circ} \mathrm{C}$ for 24 hours of exposure.

Due to the lack of quality control information on chia seeds, the objective was to establish the methodology of the electrical conductivity and accelerated aging tests to evaluate the physiological quality of seeds of this species.

\section{Material and Methods}

Chia seeds from the 2014/2015 crop from producers in the region of Chapadão do Sul, Mato Grosso do Sul (MS), Brazil, were used. Up to the time of the tests, the seeds were stored in paper bags and conditioned in a humidity chamber at controlled temperature $\left(20{ }^{\circ} \mathrm{C}\right.$ and $70 \%$ humidity). The experimental design was a completely randomized design, with five seed lots being used, and the treatments for the electrical conductivity test constituted in the amount of seeds (50 and $100)$, volume of distilled water (25 and $50 \mathrm{~mL}$ ), soaking period (1, 2, 4, 6, 12, 18 and 24 hours) and temperature $\left(20,25\right.$ and $\left.30^{\circ} \mathrm{C}\right)$ and for the accelerated aging test, the treatments were aging periods (24, 48, 72 and 96 hours) and temperature $\left(38,41\right.$ and $\left.44{ }^{\circ} \mathrm{C}\right)$, both with four replicates. The comparison of means was done by the Scott-Knott test at 5\% probability, using the Sisvar program, separately for each treatment, was not constituted a factorial.

For all the lots, the water content and the initial quality evaluation were determined through germination tests, seedling emergence and emergency speed index. The determination of the water content was performed using the oven method at $105 \pm 3{ }^{\circ} \mathrm{C}$ for 24 hours, with two replicates containing approximately $2 \mathrm{~g}$ of seeds for each lot (BRASIL, 2009).

The germination test was carried out with four replicates of 50 seeds in transparent gerbox $(11.5 \mathrm{x}$ $11.5 \times 3.5 \mathrm{~cm}$ ) containing a sheet of blotting paper, moistened with distilled water at the equivalent of 2.5 times the mass of the non-hydrated paper, where they were kept in a germination with constant temperature of $25 \pm 2{ }^{\circ} \mathrm{C}$ (SORANA et al., 2019). Evaluations were performed seven days after the test installation and the results were expressed as percentage of normal seedlings (SORANA et al., 2019).

For the emergency test, four replicates of 50 seeds were used, seeded in trays of expanded polystyrene with 200 cells, containing commercial substrate and conditioned in a greenhouse with two daily irrigations carried out. The counting was performed at seven days and the results were expressed as percentage of normal emerged seedlings. Together with the emergency test, the emergency speed index was evaluated (MAGUIRE, 1962).

For the electrical conductivity test, the chia seed lots were submitted to changes in the volume of distilled water ( 25 and $50 \mathrm{~mL}$ ), the number of seeds (50 and 100), the temperature $\left(20,25\right.$ and $30{ }^{\circ} \mathrm{C}$ ) and in the soaking period $(1,2,4,6,12,18$ and 24 hours), four replicates were used for each lot. The seeds were weighed in a precision analytical balance with $0.0001 \mathrm{~g}$ and they were then placed to soak in distilled water in $200 \mathrm{~mL}$ disposable cups and kept in the Malgelsdorf germination for the above described soaking periods at each temperature evaluated. After each soaking period, the electrical conductivity was read with the help of the portable conductivity meter, and the values were expressed in $\mu \mathrm{S} \mathrm{cm}^{-1} \mathrm{~g}^{-1}$ of seed.

The accelerated aging test in the traditional procedure was conducted using transparent plastic boxes $(11.5 \times 11.5 \times 3.5 \mathrm{~cm})$ with individual compartments (mini-chambers), having supports 
for screen support metal in their interior. As the chia seed is small, a piece of tulle (fine, transparent, malleable and porous polyester fabric) was used on the canvas. On the surface of each one, approximately $4.0 \mathrm{~g}$ of seeds were distributed in a single layer for each lot.

There were $40 \mathrm{~mL}$ of distilled water placed to control the relative air humidity inside the boxes. Subsequently, the boxes were capped and maintained in Biochemical Oxygen Demand (B.O.D.) during the aging periods of 24, 48, 72 and 96 hours, using three temperatures of 38,41 and $44{ }^{\circ} \mathrm{C}$. After each aging period, the seeds were submitted to the germination test, and the evaluation was performed four days after the test, first count day (SORANA et al., 2019). The results were expressed as percentage of normal seedlings. Also, the water content of the seeds was determined after each aging period.
The accelerated aging test with saturated $\mathrm{NaCl}$ solution was conducted in the same way as the traditional procedure (just water under the seeds). However, $40 \mathrm{~mL}$ of saturated $\mathrm{NaCl}$ solution was added to the bottom of the plastic box to replace the water. This solution was obtained by mixing $40 \mathrm{~g}$ of $\mathrm{NaCl}$ in $100 \mathrm{ml}$ of distilled water, thereby establishing an environment with $76 \%$ relative humidity (JIANHUA; MCDONALD, 1996).

\section{Result and Discussion}

The initial water content of the chia seed lots ranged from 8.22 to $9.22 \%$ (Table 1), whose difference is acceptable, according to Marcos Filho (2015). This fact is important in the execution of the tests and it uniformity in the water content between the seed lots is essential, favoring the achievement of consistent results.

Table 1. Characterization of the initial quality of chia seeds by water content (TA), germination (GERM), seedling emergence (EMER) and emergency speed index (IVE).

\begin{tabular}{ccccc}
\hline LOTS & TA $(\%)$ & GERM $(\%)$ & EMER $(\%)$ & IVE - \\
\hline 1 & 8.22 & $86 \mathrm{a}$ & $51 \mathrm{~b}$ & $0.61 \mathrm{~b}$ \\
2 & 9.09 & $88 \mathrm{a}$ & $81 \mathrm{a}$ & $1.00 \mathrm{a}$ \\
3 & 9.11 & $87 \mathrm{a}$ & $83 \mathrm{a}$ & $1.14 \mathrm{a}$ \\
4 & 9.22 & $72 \mathrm{~b}$ & $56 \mathrm{~b}$ & $0.82 \mathrm{~b}$ \\
5 & 9.22 & $72 \mathrm{~b}$ & $52 \mathrm{~b}$ & $0.78 \mathrm{~b}$ \\
\hline $\mathrm{F}$ & - & $15.90^{*}$ & $23.87^{*}$ & $5.63^{*}$ \\
\hline CV\% & - & 5.04 & 10.14 & 19.96 \\
\hline
\end{tabular}

* Means followed by the same letter in the column do not differ by Scott-Knott's test at $5 \%$ probability.

In the germination test (Table 1), lots 1, 2 and 3 presented higher germinative potential. The emergence and emergency speed indexes (IVE) highlighted lots 2 and 3 as the most vigorous and lots 1,4 and 5 as less vigorous (Table 1). The emergency tests and emergency speed index (Table 1) were efficient in the identification and separation of the lots in the physiological potential. However, the period of execution of these tests is high (seven days) and may delay the decision on the lot's destination. Thus, the search for other vigor tests is necessary and should be similar to the emergency test (MARCOS FILHO; NOVEMBRE, 2009), in which vigorous seeds express their maximum physiological potential for establishment of the crop under adverse conditions. 
Electrical conductivity test

At the temperature of $20{ }^{\circ} \mathrm{C}$, there was no separation of the lots when $25 \mathrm{~mL}$ of water was used, for both 50 and 100 seeds (Table 2). The separation of the lots in two classes of vigor was only possible with $50 \mathrm{~mL}$, from two hours of soaking using 50 seeds, and from 12 hours of soaking to 100 seeds.
However, at $20^{\circ} \mathrm{C}$, the lot ranking was not similar to the emergency test (Table 2), and the temperature was not adequate to conduct the electric conductivity test on chia seeds. This fact is related to the slower process of reorganization of cell membranes at low temperatures and the period of leachate release by the seeds to be longer (GIVELBERG et al., 1984).

Table 2. Electrical conductivity $\left(\mu \mathrm{S} \mathrm{cm}^{-1} \mathrm{~g}^{-1}\right)$ of chia seeds at a temperature of $20^{\circ} \mathrm{C}$ using combinations of 25 and 50 $\mathrm{mL}$ of water with 50 and 100 seeds, during several soaking periods.

\begin{tabular}{|c|c|c|c|c|c|c|c|}
\hline \multicolumn{8}{|c|}{$20^{\circ} \mathrm{C}$} \\
\hline \multicolumn{8}{|c|}{$25 \mathrm{~mL}$ for 50 seeds } \\
\hline \multicolumn{8}{|c|}{ Soaking periods (h) } \\
\hline Lots & 1 & 2 & 4 & 6 & 12 & 18 & 24 \\
\hline 1 & 53.42 & 106.02 & 142.76 & 167.41 & 232.47 & 257.08 & 297.57 \\
\hline 2 & 46.83 & 104.74 & 158.81 & 185.91 & 236.07 & 271.06 & 202.04 \\
\hline 3 & 83.72 & 146.14 & 165.66 & 196.06 & 270.17 & 327.97 & 369.98 \\
\hline 4 & 62.85 & 110.31 & 149.00 & 192.43 & 235.44 & 286.59 & 297.93 \\
\hline 5 & 59.33 & 129.52 & 180.52 & 199.89 & 270.56 & 317.65 & 345.15 \\
\hline $\mathrm{F}$ & $0.53^{\text {ns }}$ & $1.72^{\mathrm{ns}}$ & $1.26^{\mathrm{ns}}$ & $0.44^{\mathrm{ns}}$ & $1.03^{\mathrm{ns}}$ & $1.76^{\mathrm{ns}}$ & $1.35^{\mathrm{ns}}$ \\
\hline $\mathrm{CV} \%$ & 62.73 & 22.92 & 16.49 & 20.42 & 15.55 & 15.59 & 17.74 \\
\hline \multicolumn{8}{|c|}{$25 \mathrm{~mL}$ for 100 seeds } \\
\hline Lots & 1 & 2 & 4 & 6 & 12 & 18 & 24 \\
\hline 1 & 61.52 & 92.41 & 180.64 & 172.03 & 283.10 & 328.44 & 348.85 \\
\hline 2 & 64.68 & 112.03 & 159.24 & 186.84 & 230.14 & 277.27 & 304.83 \\
\hline 3 & 85.20 & 128.22 & 182.26 & 207.46 & 259.89 & 295.02 & 316.07 \\
\hline 4 & 32.63 & 104.62 & 170.84 & 209.04 & 269.62 & 300.33 & 336.30 \\
\hline 5 & 44.67 & 98.30 & 167.74 & 200.24 & 269.23 & 319.30 & 353.96 \\
\hline $\mathrm{F}$ & $2.44^{\mathrm{ns}}$ & $0.63^{\mathrm{ns}}$ & $0.77^{\mathrm{ns}}$ & $1.19^{\mathrm{ns}}$ & $2.47^{\mathrm{ns}}$ & $2.67^{\mathrm{ns}}$ & $2.02^{\mathrm{ns}}$ \\
\hline $\mathrm{CV} \%$ & 44.59 & 32.39 & 12.61 & 14.63 & 9.62 & 8.15 & 8.94 \\
\hline \multicolumn{8}{|c|}{$50 \mathrm{~mL}$ for 50 seeds } \\
\hline Lots & 1 & 2 & 4 & 6 & 12 & 18 & 24 \\
\hline 1 & 36.52 & $56.76 \mathrm{a}$ & $74.32 \mathrm{a}$ & 82.49 a & 106.89 a & $124.35 \mathrm{a}$ & $125.69 \mathrm{a}$ \\
\hline 2 & 38.00 & $57.00 \mathrm{a}$ & $64.64 \mathrm{a}$ & $80.02 \mathrm{a}$ & $102.86 \mathrm{a}$ & $110.56 \mathrm{a}$ & $121.80 \mathrm{a}$ \\
\hline 3 & 37.73 & $63.96 \mathrm{a}$ & $75.36 \mathrm{a}$ & $86.62 \mathrm{a}$ & $109.18 \mathrm{a}$ & $112.85 \mathrm{a}$ & $131.60 \mathrm{a}$ \\
\hline 4 & 45.09 & $71.16 \mathrm{~b}$ & $89.91 \mathrm{~b}$ & $104.86 \mathrm{~b}$ & $138.61 \mathrm{~b}$ & $149.84 \mathrm{~b}$ & $168.29 \mathrm{~b}$ \\
\hline 5 & 46.73 & $73.67 \mathrm{~b}$ & $88.88 \mathrm{~b}$ & $104.38 \mathrm{~b}$ & $135.19 \mathrm{~b}$ & $150.61 \mathrm{~b}$ & $173.87 \mathrm{~b}$ \\
\hline $\mathrm{F}$ & $0.75^{\mathrm{ns}}$ & $3.68 *$ & $5.99 *$ & $5.65 *$ & $8.42 *$ & $6.80 *$ & $15.92 *$ \\
\hline $\mathrm{CV} \%$ & 26.65 & 12.65 & 11.11 & 11.06 & 9.85 & 11.53 & 8.62 \\
\hline
\end{tabular}

continue 
continuation

\begin{tabular}{cccccccc}
\hline \multicolumn{1}{c}{$50 \mathrm{~mL}$ for 100 seeds } \\
\hline Lots & 1 & 2 & 4 & 6 & 12 & 18 & 24 \\
\hline 1 & 40.15 & 58.22 & 80.31 & 92.34 & $124.54 \mathrm{~b}$ & $130.61 \mathrm{a}$ & $140.71 \mathrm{a}$ \\
2 & 35.08 & 52.50 & 70.04 & 83.61 & $108.86 \mathrm{a}$ & $118.59 \mathrm{a}$ & $128.34 \mathrm{a}$ \\
3 & 39.91 & 72.14 & 85.47 & 93.06 & $119.69 \mathrm{~b}$ & $127.17 \mathrm{a}$ & $140.42 \mathrm{a}$ \\
4 & 34.69 & 63.46 & 84.75 & 96.40 & $132.90 \mathrm{~b}$ & $146.31 \mathrm{~b}$ & $156.10 \mathrm{~b}$ \\
5 & 34.25 & 64.79 & 83.76 & 93.32 & $119.96 \mathrm{~b}$ & $137.08 \mathrm{~b}$ & $152.26 \mathrm{~b}$ \\
\hline $\mathrm{F}$ & $0.17^{\mathrm{ns}}$ & $1.68^{\mathrm{ns}}$ & $2.73^{\mathrm{ns}}$ & $1.31^{\mathrm{ns}}$ & $5.94^{*}$ & $5.47^{*}$ & $6.87^{*}$ \\
\hline $\mathrm{CV} \%$ & 38.59 & 18.25 & 9.53 & 9.14 & 5.90 & 6.76 & 5.84 \\
\hline
\end{tabular}

* Means followed by the same letter in the column do not differ by Scott-Knott's test at $5 \%$ probability.

At $25^{\circ} \mathrm{C}$ with a volume of $25 \mathrm{~mL}$ of water and 50 seeds (Table 3 ) it was possible to obtain the lot order similar to the emergency test in the 12 and 24 hour periods. Using the same volume of water and 100 seeds the same ordering of lots was carried out in the six-hour period. Using a combination of $50 \mathrm{~mL}$ for 100 seeds the lot classification similar to the seedling emergence test was possible within four hours.

Table 3. Electrical conductivity $\left(\mu \mathrm{S} \mathrm{cm} \mathrm{cm}^{-1} \mathrm{~g}^{-1}\right)$ of chia seeds at $25^{\circ} \mathrm{C}$ using combinations of 25 and $50 \mathrm{~mL}$ of water with 50 and 100 seeds, during several soaking periods.

\begin{tabular}{|c|c|c|c|c|c|c|c|}
\hline \multicolumn{8}{|c|}{$25^{\circ} \mathrm{C}$} \\
\hline \multicolumn{8}{|c|}{$25 \mathrm{~mL}$ for 50 seeds } \\
\hline \multicolumn{8}{|c|}{ Soaking periods (h) } \\
\hline Lots & 1 & 2 & 4 & 6 & 12 & 18 & 24 \\
\hline 1 & 89.07 & 125.44 & 227.35 & 276.09 & $337.11 \mathrm{~b}$ & $357.87 \mathrm{~b}$ & $390.15 \mathrm{~b}$ \\
\hline 2 & 90.03 & 121.49 & 176.06 & 219.39 & $289.87 \mathrm{a}$ & $305.37 \mathrm{a}$ & $325.14 \mathrm{a}$ \\
\hline 3 & 57.57 & 107.76 & 188.49 & 234.79 & $284.73 \mathrm{a}$ & $304.25 \mathrm{a}$ & $322.92 \mathrm{a}$ \\
\hline 4 & 72.06 & 120.01 & 213.93 & 262.58 & $353.08 \mathrm{~b}$ & $427.38 \mathrm{c}$ & $420.40 \mathrm{~b}$ \\
\hline 5 & 84.42 & 144.55 & 200.91 & 249.00 & $325.10 \mathrm{~b}$ & $357.47 \mathrm{~b}$ & $377.36 \mathrm{~b}$ \\
\hline $\mathrm{F}$ & $0.61^{\mathrm{ns}}$ & $0.94^{\mathrm{ns}}$ & $2.88^{\mathrm{ns}}$ & $2.44^{\mathrm{ns}}$ & $3.44^{*}$ & $7.60 *$ & $5.72 *$ \\
\hline $\mathrm{CV} \%$ & 44.80 & 22.10 & 11.86 & 11.50 & 10.10 & 10.45 & 9.65 \\
\hline \multicolumn{8}{|c|}{$25 \mathrm{~mL}$ for 100 seeds } \\
\hline Lots & 1 & 2 & 4 & 6 & 12 & 18 & 24 \\
\hline 1 & $51.43 \mathrm{a}$ & 134.98 & $214.76 \mathrm{~b}$ & $255.85 \mathrm{~b}$ & $312.83 \mathrm{a}$ & $341.44 \mathrm{a}$ & $353.62 \mathrm{a}$ \\
\hline 2 & $85.07 \mathrm{~b}$ & 122.22 & $164.85 \mathrm{a}$ & $219.37 \mathrm{a}$ & $263.98 \mathrm{a}$ & $295.14 \mathrm{a}$ & $312.46 \mathrm{a}$ \\
\hline 3 & $63.16 \mathrm{a}$ & 103.90 & $194.75 \mathrm{a}$ & $237.53 \mathrm{a}$ & $296.81 \mathrm{a}$ & $335.78 \mathrm{a}$ & $354.31 \mathrm{a}$ \\
\hline 4 & $58.94 \mathrm{a}$ & 114.24 & $222.34 \mathrm{~b}$ & $287.11 \mathrm{~b}$ & $376.13 \mathrm{~b}$ & $448.42 \mathrm{c}$ & $476.60 \mathrm{~b}$ \\
\hline 5 & $67.24 \mathrm{a}$ & 111.40 & $181.16 \mathrm{a}$ & $261.73 \mathrm{~b}$ & $339.14 \mathrm{~b}$ & $388.95 \mathrm{~b}$ & $410.43 b$ \\
\hline $\mathrm{F}$ & $1.13^{\mathrm{ns}}$ & $0.55^{\mathrm{ns}}$ & $4.44 *$ & $6.78^{*}$ & $8.63 *$ & $11.78^{*}$ & $6.60^{*}$ \\
\hline $\mathrm{CV} \%$ & 36.29 & 27.29 & 10.37 & 7.78 & 9.10 & 9.45 & 12.97 \\
\hline
\end{tabular}


continuation

\begin{tabular}{|c|c|c|c|c|c|c|c|}
\hline \multicolumn{8}{|c|}{$50 \mathrm{~mL}$ for 50 seeds } \\
\hline Lots & 1 & 2 & 4 & 6 & 12 & 18 & 24 \\
\hline 1 & 33.29 & 74.79 & 99.65 & 120.48 & $145.46 \mathrm{~b}$ & $166.09 \mathrm{~b}$ & $162.12 \mathrm{~b}$ \\
\hline 2 & 22.83 & 69.00 & 76.68 & 92.01 & $107.35 \mathrm{a}$ & $111.13 \mathrm{a}$ & $126.46 \mathrm{a}$ \\
\hline 3 & 31.10 & 65.60 & 92.41 & 104.09 & $134.91 \mathrm{~b}$ & $146.43 \mathrm{~b}$ & $158.11 \mathrm{~b}$ \\
\hline 4 & 29.08 & 72.71 & 98.20 & 116.32 & $156.35 \mathrm{~b}$ & $174.58 \mathrm{~b}$ & $181.75 \mathrm{~b}$ \\
\hline 5 & 34.06 & 74.92 & 97.24 & 119.68 & $157.27 \mathrm{~b}$ & $183.48 \mathrm{~b}$ & $187.30 \mathrm{~b}$ \\
\hline $\mathrm{F}$ & $0.79^{\text {ns }}$ & $0.36^{\mathrm{ns}}$ & $1.22^{\mathrm{ns}}$ & $2.46^{\mathrm{ns}}$ & $3.79 *$ & $3.68^{*}$ & $3.36^{*}$ \\
\hline $\mathrm{CV} \%$ & 41.89 & 18.76 & 18.40 & 14.15 & 15.04 & 19.16 & 16.04 \\
\hline \multicolumn{8}{|c|}{$50 \mathrm{~mL}$ for 100 seeds } \\
\hline Lots & 1 & 2 & 4 & 6 & 12 & 18 & 24 \\
\hline 1 & 33.62 & 77.66 & $100.78 \mathrm{~b}$ & $117.48 \mathrm{~b}$ & $142.62 \mathrm{a}$ & $153.17 \mathrm{a}$ & $153.20 \mathrm{a}$ \\
\hline 2 & 26.18 & 59.78 & 80.67 a & $95.47 \mathrm{a}$ & $114.42 \mathrm{a}$ & $125.80 \mathrm{a}$ & $140.64 \mathrm{a}$ \\
\hline 3 & 30.94 & 78.89 & $92.25 \mathrm{a}$ & $115.52 \mathrm{~b}$ & $140.21 \mathrm{a}$ & $150.06 \mathrm{a}$ & $157.79 \mathrm{a}$ \\
\hline 4 & 27.69 & 79.02 & $110.51 \mathrm{~b}$ & $130.25 \mathrm{~b}$ & $169.75 \mathrm{~b}$ & $207.51 \mathrm{~b}$ & $201.53 \mathrm{~b}$ \\
\hline 5 & 41.51 & 87.38 & $115.05 \mathrm{~b}$ & $135.01 \mathrm{~b}$ & $176.77 \mathrm{~b}$ & $209.65 \mathrm{~b}$ & $205.89 \mathrm{~b}$ \\
\hline $\mathrm{F}$ & $1.41^{\mathrm{ns}}$ & $2.65^{\text {ns }}$ & $4.19 *$ & $5.30 *$ & $7.16^{*}$ & $6.02 *$ & $5.12 *$ \\
\hline $\mathrm{CV} \%$ & 31.85 & 16.29 & 13.58 & 11.28 & 12.60 & 18.03 & 15.34 \\
\hline
\end{tabular}

* Means followed by the same letter in the column do not differ by Scott-Knott's test at 5\% probability.

Most of the temperature works on soaking of the electrical conductivity test recommends $25^{\circ} \mathrm{C}$, since it is the most usual in the internal conditions of the seed analysis laboratories, it has been adequate to evaluate the physiological quality of seeds (VIEIRA; KRZYZANOWSKI, 1999). Works with black oat seeds (MENEZES et al., 2007), arugula (TORRES; PEREIRA, 2010) and ryegrass (LOPES; FRANKE, 2010) observed that the temperature of $25^{\circ} \mathrm{C}$ was the most adequate for this test. In this study, it was found that the temperature of $25{ }^{\circ} \mathrm{C}$ was also adequate for conducting the test, using the combination $50 \mathrm{~mL}$ for 100 seeds in the four-hour soaking period.

The highest values of electrical conductivity were observed at $30{ }^{\circ} \mathrm{C}$, being proportional to the temperature increase, that is, there was an increase in temperature from 20 to 25 or $30{ }^{\circ} \mathrm{C}$, providing increases in the leaching of the exudates. This fact is due to the possible damages to cell membranes, increasing the activation energy of the molecules, altering the viscosity of the water and, consequently, increasing the electrical conductivity values (VIEIRA, 1994). Work done with arugula seeds (ALVES; SÁ, 2009) and sesame (TORRES et al., 2009) also obtained an increase in the values of electrical conductivity with the increase of temperature and soaking period.

When the combination of $50 \mathrm{~mL}$ for 100 seeds at a temperature of $30^{\circ} \mathrm{C}$ (Table 4 ) was used, lot sorting similar to the emergency test was observed in the four, 12 and 18 hour soaking periods, showing that it is possible the reduction of the time to perform the electrical conductivity test on chia seeds, allowing quick results.

Seeds soaked in $25 \mathrm{~mL}$ of water had the highest values of electrical conductivity compared to 50 $\mathrm{mL}$, regardless of temperature, seed quantity and soaking period. This fact is due to the increase in the concentration of leachate in the solution due to the reduction of the water volume. Some combinations using the smaller volumes ( 25 and $50 \mathrm{~mL}$ ) provided ranks of lots similar to the emergency test (Tables 
3 and 4), and with $50 \mathrm{~mL}$, it was possible to reduce the reading to four hours (Tables 3 and 4).

With the advancement of the soaking period, there was a progressive increase in the conductivity readings. At temperatures of 25 and $30{ }^{\circ} \mathrm{C}$, using $50 \mathrm{~mL}$ for 100 seeds, it was possible to rank lots similar to the emergency starting from four hours of soaking, reducing the conductivity test execution period.

Keeping constant the temperature, water volume and soaking period, the increase in seed quantity provided a small increment of leachate in most combinations (Tables 2, 3 and 4). For both 50 and 100 seeds, there was consistency in the results for differentiation of lots similar to emergence; but with 100 seeds, the ranking was possible with four soaking hours (Table 3 and 4).
The results obtained by the electrical conductivity test at $25{ }^{\circ} \mathrm{C}$ (Table 3) using combinations of 25 $\mathrm{mL}$ for 50 seeds for 12 and 24 hours; $25 \mathrm{~mL}$ for 100 seeds per six hours and $50 \mathrm{~mL}$ for 100 seeds per four hours, were efficient for the classification of emergency-like lots. At $30{ }^{\circ} \mathrm{C}$ (Table 4), the combination of $50 \mathrm{~mL}$ for 100 seeds was also efficient for four, 12 and 18 hours of soaking, generating results that corroborate with emergence. Thus, for faster and accurate results, the four-hour soaking period is most appropriate for separating chia seed lots.

The electrical conductivity test is efficient to evaluate the physiological quality of chia seeds, presenting an advantage when compared to the emergence of seedlings, due to the ease of execution and quick results.

Table 4. Electrical conductivity $\left(\mu \mathrm{S} \mathrm{cm} \mathrm{cm}^{-1} \mathrm{~g}^{-1}\right)$ of chia seeds at $30{ }^{\circ} \mathrm{C}$ using combinations of 25 and $50 \mathrm{~mL}$ of water with 50 and 100 seeds at different soaking periods.

\begin{tabular}{|c|c|c|c|c|c|c|c|}
\hline \multicolumn{8}{|c|}{$30^{\circ} \mathrm{C}$} \\
\hline \multicolumn{8}{|c|}{$25 \mathrm{~mL}$ for 50 seeds } \\
\hline \multicolumn{8}{|c|}{ Soaking periods (h) } \\
\hline Lots & 1 & 2 & 4 & 6 & 12 & 18 & 24 \\
\hline 1 & 114.11 & 150.43 & 220.66 & 264.47 & 333.05 & 354.13 & $398.72 \mathrm{a}$ \\
\hline 2 & 111.82 & 130.99 & 200.30 & 227.37 & 277.05 & 312.01 & $354.48 \mathrm{a}$ \\
\hline 3 & 143.76 & 123.66 & 161.80 & 233.42 & 297.14 & 334.57 & $371.70 \mathrm{a}$ \\
\hline 4 & 129.56 & 159.70 & 211.15 & 292.90 & 378.66 & 397.23 & $452.81 \mathrm{~b}$ \\
\hline 5 & 116.37 & 138.24 & 202.11 & 258.32 & 378.20 & 408.01 & $520.04 \mathrm{~b}$ \\
\hline $\mathrm{F}$ & $0.43^{\mathrm{ns}}$ & $0.92^{\mathrm{ns}}$ & $2.02^{\mathrm{ns}}$ & $0.99^{\text {ns }}$ & $1.26^{\mathrm{ns}}$ & $1.02^{\mathrm{ns}}$ & $2.50^{\mathrm{ns}}$ \\
\hline $\mathrm{CV} \%$ & 33.16 & 21.33 & 15.85 & 20.73 & 24.74 & 22.36 & 20.30 \\
\hline \multicolumn{8}{|c|}{$25 \mathrm{~mL}$ for 100 seeds } \\
\hline Lots & 1 & 2 & 4 & 6 & 12 & 18 & 24 \\
\hline 1 & $122.59 \mathrm{~b}$ & 165.84 & $230.77 \mathrm{~b}$ & 289.52 & $328.78 \mathrm{a}$ & $412.12 \mathrm{a}$ & $449.69 \mathrm{a}$ \\
\hline 2 & $113.10 \mathrm{~b}$ & 107.29 & $177.08 \mathrm{a}$ & 238.72 & $288.65 \mathrm{a}$ & $346.42 \mathrm{a}$ & $384.95 \mathrm{a}$ \\
\hline 3 & $149.47 \mathrm{~b}$ & 127.00 & $213.35 \mathrm{~b}$ & 249.75 & $343.01 \mathrm{a}$ & $398.10 \mathrm{a}$ & $439.56 \mathrm{a}$ \\
\hline 4 & $134.37 \mathrm{~b}$ & 164.37 & $220.09 \mathrm{~b}$ & 254.26 & $446.12 \mathrm{~b}$ & $485.53 \mathrm{~b}$ & $530.35 \mathrm{~b}$ \\
\hline 5 & $71.46 \mathrm{a}$ & 132.74 & $248.33 \mathrm{~b}$ & 243.49 & $438.84 \mathrm{~b}$ & $469.59 \mathrm{~b}$ & $537.15 \mathrm{~b}$ \\
\hline $\mathrm{F}$ & $4.42 *$ & $1.33^{\text {ns }}$ & $6.34^{*}$ & $1.30^{\mathrm{ns}}$ & $13.49 *$ & $7.65^{*}$ & $6.31 *$ \\
\hline $\mathrm{CV} \%$ & 23.71 & 31.46 & 9.62 & 13.82 & 10.32 & 9.64 & 10.99 \\
\hline
\end{tabular}


continuation

\begin{tabular}{cccccccc}
\hline \multicolumn{7}{c}{$50 \mathrm{~mL}$ for 50 seeds } \\
\hline Lots & 1 & 2 & 4 & 6 & 12 & 18 & 24 \\
\hline 1 & 90.95 & 115.95 & 144.86 & 157.12 & $190.16 \mathrm{a}$ & 211.01 & 227.54 \\
2 & 87.31 & 107.42 & 131.23 & 142.98 & $170.95 \mathrm{a}$ & 190.67 & 202.75 \\
3 & 64.78 & 100.09 & 136.11 & 144.54 & $187.45 \mathrm{a}$ & 179.72 & 203.34 \\
4 & 84.06 & 116.87 & 175.07 & 189.70 & $273.45 \mathrm{~b}$ & 280.55 & 313.51 \\
5 & 82.34 & 113.21 & 148.79 & 176.10 & $238.51 \mathrm{~b}$ & 246.30 & 269.53 \\
\hline $\mathrm{F}$ & $2.11^{\text {ns }}$ & $0.44^{\text {ns }}$ & $1.97^{\text {ns }}$ & $1.96^{\text {ns }}$ & $4.55^{*}$ & $2.87^{\text {ns }}$ & $2.81^{\text {ns }}$ \\
\hline CV\% & 16.97 & 19.08 & 16.52 & 17.93 & 18.81 & 22.13 & 23.39 \\
\hline & & & $50 \mathrm{~mL}$ for 100 seeds & & & \\
\hline Lots & 1 & 2 & 4 & 6 & 12 & 18 & 24 \\
\hline 1 & $78.00 \mathrm{~b}$ & 102.62 & $133.42 \mathrm{~b}$ & $153.94 \mathrm{c}$ & $188.84 \mathrm{~b}$ & $207.31 \mathrm{~b}$ & $211.42 \mathrm{a}$ \\
2 & $66.72 \mathrm{~b}$ & 84.02 & $104.78 \mathrm{a}$ & $114.37 \mathrm{a}$ & $142.83 \mathrm{a}$ & $158.09 \mathrm{a}$ & $165.75 \mathrm{a}$ \\
3 & $48.43 \mathrm{a}$ & 90.72 & $113.54 \mathrm{a}$ & $136.80 \mathrm{~b}$ & $167.37 \mathrm{a}$ & $179.32 \mathrm{a}$ & $194.36 \mathrm{a}$ \\
4 & $68.06 \mathrm{~b}$ & 94.16 & $141.45 \mathrm{~b}$ & $162.28 \mathrm{c}$ & $222.47 \mathrm{~b}$ & $209.60 \mathrm{~b}$ & $247.03 \mathrm{~b}$ \\
5 & $59.63 \mathrm{a}$ & 101.64 & $132.33 \mathrm{~b}$ & $157.32 \mathrm{c}$ & $218.56 \mathrm{~b}$ & $226.30 \mathrm{~b}$ & $253.08 \mathrm{~b}$ \\
\hline $\mathrm{F}$ & $6.61^{*}$ & $1.62^{\text {ns }}$ & $7.04^{*}$ & $7.64^{*}$ & $9.96^{*}$ & $5.28^{*}$ & $6.08^{*}$ \\
\hline CV\% & 13.30 & 12.88 & 9.21 & 9.78 & 11.42 & 12.04 & 13.83 \\
\hline
\end{tabular}

* Means followed by the same letter in the column do not differ by Scott-Knott's test at $5 \%$ probability.

\section{Accelerated aging test}

Regardless of the temperature and the period of exposure, the use of saturated $\mathrm{NaCl}$ solution resulted in lower water content and less variation among the lots than those observed for seeds aged by the traditional procedure (Table 5). The use of saline solution promotes less drastic effects to the seeds because when reaching lower water content, the degree of deterioration of the seeds is lower than the one usually observed with the traditional method.

Table 5. Water content (\%) after the periods of traditional accelerated aging and saturated solution of $\mathrm{NaCl}$ in five lots of chia seeds.

\begin{tabular}{ccccccccc}
\hline \multicolumn{10}{c}{$38^{\circ} \mathrm{C}$} \\
\hline \multirow{2}{*}{ Lots } & \multicolumn{10}{c}{-------Traditional-------- } & \multicolumn{5}{c}{-- Saturated NaCl Solution -- } \\
& $24 \mathrm{~h}$ & $48 \mathrm{~h}$ & $72 \mathrm{~h}$ & $96 \mathrm{~h}$ & $24 \mathrm{~h}$ & $48 \mathrm{~h}$ & $72 \mathrm{~h}$ & $96 \mathrm{~h}$ \\
\hline 1 & 22.01 & 22.24 & 24.38 & 24.63 & 9.15 & 9.37 & 9.34 & 9.46 \\
2 & 22.66 & 23.28 & 24.48 & 26.83 & 9.45 & 9.35 & 9.35 & 9.37 \\
3 & 23.96 & 24.13 & 22.75 & 25.92 & 9.45 & 9.45 & 9.37 & 9.57 \\
4 & 23.40 & 23.49 & 22.78 & 24.24 & 9.55 & 9.55 & 9.62 & 9.60 \\
5 & 24.06 & 24.81 & 23.53 & 25.37 & 9.49 & 9.39 & 9.33 & 9.51 \\
\hline
\end{tabular}

continue 
continuation

\begin{tabular}{|c|c|c|c|c|c|c|c|c|}
\hline \multicolumn{9}{|c|}{$41{ }^{\circ} \mathrm{C}$} \\
\hline \multirow{2}{*}{ Lots } & \multicolumn{4}{|c|}{----------Traditional---------- } & \multicolumn{4}{|c|}{-- Saturated $\mathrm{NaCl}$ Solution -- } \\
\hline & $24 \mathrm{~h}$ & $48 \mathrm{~h}$ & $72 \mathrm{~h}$ & $96 \mathrm{~h}$ & $24 \mathrm{~h}$ & $48 \mathrm{~h}$ & $72 \mathrm{~h}$ & $96 \mathrm{~h}$ \\
\hline 1 & 22.22 & 24.60 & 25.47 & 23.69 & 9.92 & 9.26 & 9.36 & 9.69 \\
\hline 2 & 24.26 & 22.81 & 23.82 & 23.77 & 9.94 & 9.87 & 9.51 & 9.38 \\
\hline 3 & 19.68 & 22.68 & 24.08 & 23.04 & 10.64 & 7.98 & 9.33 & 9.34 \\
\hline 4 & 24.09 & 23.65 & 24.95 & 25.07 & 10.55 & 9.83 & 9.74 & 9.71 \\
\hline 5 & 23.89 & 25.04 & 24.78 & 24.55 & 10.24 & 9.69 & 9.68 & 9.38 \\
\hline \multicolumn{9}{|c|}{$44^{\circ} \mathrm{C}$} \\
\hline \multirow{2}{*}{ Lots } & \multicolumn{4}{|c|}{-----------Traditional----------- } & \multicolumn{4}{|c|}{-- Saturated NaCl Solution-- } \\
\hline & $24 \mathrm{~h}$ & $48 \mathrm{~h}$ & $72 \mathrm{~h}$ & $96 \mathrm{~h}$ & $24 \mathrm{~h}$ & $48 \mathrm{~h}$ & $72 \mathrm{~h}$ & $96 \mathrm{~h}$ \\
\hline 1 & 20.46 & 23.44 & 23.29 & 22.80 & 9.26 & 8.89 & 8.95 & 9.21 \\
\hline 2 & 21.31 & 16.02 & 22.89 & 22.59 & 9.18 & 8.87 & 9.00 & 9.05 \\
\hline 3 & 21.47 & 24.33 & 24.49 & 24.58 & 9.26 & 9.06 & 9.11 & 9.35 \\
\hline 4 & 22.34 & 26.54 & 24.07 & 24.46 & 9.28 & 8.99 & 9.01 & 9.33 \\
\hline 5 & 21.95 & 24.88 & 26.40 & 28.03 & 9.26 & 9.07 & 9.15 & 9.27 \\
\hline
\end{tabular}

The combination of $44{ }^{\circ} \mathrm{C}$ for 24 hours with saturated solution of $\mathrm{NaCl}$ provided a greater reduction in the soaking speed and uniformity in the process of water absorption by the seeds (Table 5). The use of the saturated $\mathrm{NaCl}$ solution also contributed to reduce the incidence of fungi during the conduction of the test. This was probably due to the restriction of the relative humidity of the environment inside the plastic boxes, which made the environment unfavorable for the proliferation of these microorganisms. Similar findings were observed by Souza et al. (2009) in black oat seeds and Tunes et al. (2011) and Radke et al. (2016) found similarities in coriander seeds.

In the accelerated aging test by the traditional method (Table 6), it was verified that in all the temperatures and periods of exposure, there was differentiation of lots for vigor; but only at the temperature of $44^{\circ} \mathrm{C}$ for 24 hours, it was possible to classify the emergency test (Table 1).
In the 96-hour period at $44{ }^{\circ} \mathrm{C}$, there was a drastic reduction in germination (Table 6). This was probably due to the intensification of the deterioration process, reducing the viability of the seeds, especially in lots that have high water content when subjected to long periods of exposure to high temperatures. This fact was also verified in parsley seeds (TUNES et al., 2013), broccoli (TUNES et al., 2012) and coriander (TUNES et al., 2011). Seed deterioration can cause protein denaturation, decrease in carbohydrate content, increase of free fatty acids and reducing sugars, and synthesis of RNA due to loss of membrane system integrity (lipid peroxidation). Such metabolic and/or biochemical manifestations occur during preparatory activities for germination, reducing seed viability (MARCOS FILHO, 2015), which may explain the fall in germination of chia seeds in the period of 96 hours at $44{ }^{\circ} \mathrm{C}$. 
Table 6. Percentage of germination after the accelerated aging test by the traditional procedure in five lots of chia seeds.

\begin{tabular}{|c|c|c|c|c|}
\hline \multicolumn{5}{|c|}{$38^{\circ} \mathrm{C}$} \\
\hline Lots & $24 \mathrm{~h}$ & $48 \mathrm{~h}$ & $72 \mathrm{~h}$ & $96 \mathrm{~h}$ \\
\hline 1 & $69 \mathrm{~b}$ & $78 \mathrm{~b}$ & $64 \mathrm{a}$ & $70 \mathrm{a}$ \\
\hline 2 & $86 \mathrm{a}$ & $88 \mathrm{a}$ & $57 \mathrm{~b}$ & $66 \mathrm{a}$ \\
\hline 3 & $83 \mathrm{a}$ & $76 \mathrm{~b}$ & $41 \mathrm{c}$ & $56 \mathrm{~b}$ \\
\hline 4 & $77 \mathrm{a}$ & $69 \mathrm{c}$ & $42 \mathrm{c}$ & $33 c$ \\
\hline 5 & $62 \mathrm{~b}$ & $67 \mathrm{c}$ & $17 \mathrm{~d}$ & $12 \mathrm{~d}$ \\
\hline $\mathrm{F}$ & $10.23 *$ & $9.18^{*}$ & $55.63^{*}$ & $65.93 *$ \\
\hline $\mathrm{CV} \%$ & 8.15 & 7.21 & 11.00 & 12.58 \\
\hline \multicolumn{5}{|c|}{$41^{\circ} \mathrm{C}$} \\
\hline Lots & $24 \mathrm{~h}$ & $48 \mathrm{~h}$ & $72 \mathrm{~h}$ & $96 \mathrm{~h}$ \\
\hline 1 & $75 \mathrm{a}$ & $76 \mathrm{a}$ & $72 \mathrm{a}$ & $53 \mathrm{a}$ \\
\hline 2 & $88 \mathrm{a}$ & $80 \mathrm{a}$ & $70 \mathrm{a}$ & $38 \mathrm{~b}$ \\
\hline 3 & $77 \mathrm{a}$ & $75 \mathrm{a}$ & $65 \mathrm{a}$ & $36 \mathrm{~b}$ \\
\hline 4 & $78 \mathrm{a}$ & $63 \mathrm{~b}$ & $53 \mathrm{~b}$ & $22 \mathrm{c}$ \\
\hline 5 & $65 \mathrm{~b}$ & $50 \mathrm{c}$ & $29 \mathrm{c}$ & $12 \mathrm{c}$ \\
\hline $\mathrm{F}$ & $5.47 *$ & $10.46^{*}$ & $29.99 *$ & $16.23^{*}$ \\
\hline $\mathrm{CV} \%$ & 8.92 & 10.92 & 11.08 & 24.06 \\
\hline \multicolumn{5}{|c|}{$44^{\circ} \mathrm{C}$} \\
\hline Lots & $24 \mathrm{~h}$ & $48 \mathrm{~h}$ & $72 \mathrm{~h}$ & $96 \mathrm{~h}$ \\
\hline 1 & $70 \mathrm{~b}$ & $52 \mathrm{~b}$ & $47 \mathrm{a}$ & $18 \mathrm{~b}$ \\
\hline 2 & $80 \mathrm{a}$ & $74 \mathrm{a}$ & $51 \mathrm{a}$ & $42 \mathrm{a}$ \\
\hline 3 & $76 \mathrm{a}$ & $59 \mathrm{~b}$ & $48 \mathrm{a}$ & $17 \mathrm{~b}$ \\
\hline 4 & $71 \mathrm{~b}$ & $52 \mathrm{~b}$ & $44 \mathrm{a}$ & $6 \mathrm{c}$ \\
\hline 5 & $65 \mathrm{~b}$ & $63 \mathrm{~b}$ & $12 \mathrm{~b}$ & $2 \mathrm{c}$ \\
\hline $\mathrm{F}$ & $8.56^{*}$ & $4.28 *$ & $7.50 *$ & $21.37^{*}$ \\
\hline CV\% & 3.70 & 14.66 & 29.12 & 39.29 \\
\hline
\end{tabular}

* Means followed by the same letter in the column do not differ by Scott-Knott's test at $5 \%$ probability.

In the accelerated aging test with saturated $\mathrm{NaCl}$ solution (Table 7), lot differentiation was also observed for vigor at all temperatures and periods of exposure. However, the same emergency lot ranking was obtained at $38{ }^{\circ} \mathrm{C}$ for 48 hours, $41^{\circ} \mathrm{C}$ for 24 hours and $44{ }^{\circ} \mathrm{C}$ for 72 hours. Considering that the speed in obtaining results is one of the objectives of the vigor tests, it is more appropriate to use 24 hours of seed exposure, both for the traditional methodology and for saturated $\mathrm{NaCl}$ solution. Some studies also showed a reduction of the time to obtain the results by accelerated aging test, for example, in ryegrass seeds (LOPES et al., 2009), gilo (ALVES et al., 2012), Lettuce (BARBOSA et al., 2011) and coriander (RADKE et al., 2016).

The germination was not drastically reduced with the use of saturated $\mathrm{NaCl}$ solution, maintaining high values (Table 7). This fact is probably due to the low water content acquired by the seeds after aging (Table 5). The same was observed by Souza et al. (2009) in black oat seeds, by Tunes et al. (2011) in coriander seeds and by Tunes et al. (2012) in broccoli seeds. 
Table 7. Percentage of germination after the accelerated aging test by saturated $\mathrm{NaCl}$ solution in five lots of chia seeds.

\begin{tabular}{|c|c|c|c|c|}
\hline \multicolumn{5}{|c|}{$38^{\circ} \mathrm{C}$} \\
\hline Lots & $24 \mathrm{~h}$ & $48 \mathrm{~h}$ & $72 \mathrm{~h}$ & $96 \mathrm{~h}$ \\
\hline 1 & $79 \mathrm{a}$ & $71 \mathrm{~b}$ & $81 \mathrm{a}$ & $79 \mathrm{a}$ \\
\hline 2 & $82 \mathrm{a}$ & $85 \mathrm{a}$ & $89 \mathrm{a}$ & $88 \mathrm{a}$ \\
\hline 3 & 79 a & $80 \mathrm{a}$ & $83 \mathrm{a}$ & $77 \mathrm{a}$ \\
\hline 4 & $76 \mathrm{a}$ & $75 \mathrm{~b}$ & $77 \mathrm{~b}$ & $76 \mathrm{a}$ \\
\hline 5 & $68 \mathrm{~b}$ & $65 \mathrm{~b}$ & $70 \mathrm{~b}$ & $64 \mathrm{~b}$ \\
\hline$F$ & $3.66^{*}$ & $6.45^{*}$ & $5.54^{*}$ & $5.26^{*}$ \\
\hline CV\% & 7.00 & 8.27 & 7.32 & 9.91 \\
\hline \multicolumn{5}{|c|}{$41^{\circ} \mathrm{C}$} \\
\hline Lots & $24 \mathrm{~h}$ & $48 \mathrm{~h}$ & $72 \mathrm{~h}$ & $96 \mathrm{~h}$ \\
\hline 1 & $75 \mathrm{~b}$ & $68 \mathrm{~b}$ & $79 \mathrm{a}$ & $79 \mathrm{~b}$ \\
\hline 2 & $91 \mathrm{a}$ & 86 a & $85 \mathrm{a}$ & $92 \mathrm{a}$ \\
\hline 3 & $84 \mathrm{a}$ & $76 \mathrm{~b}$ & $76 \mathrm{a}$ & $81 \mathrm{~b}$ \\
\hline 4 & 77 b & $73 \mathrm{~b}$ & $68 \mathrm{~b}$ & $73 \mathrm{c}$ \\
\hline 5 & $75 \mathrm{~b}$ & $69 \mathrm{~b}$ & $71 \mathrm{~b}$ & $61 \mathrm{~d}$ \\
\hline $\mathrm{F}$ & $4.84^{*}$ & $6.25^{*}$ & $4.59^{*}$ & $29.88^{*}$ \\
\hline CV\% & 8.80 & 7.63 & 8.13 & 5.46 \\
\hline \multicolumn{5}{|c|}{$44^{\circ} \mathrm{C}$} \\
\hline Lots & $24 \mathrm{~h}$ & $48 \mathrm{~h}$ & $72 \mathrm{~h}$ & $96 \mathrm{~h}$ \\
\hline 1 & $75 \mathrm{~b}$ & $78 \mathrm{~b}$ & $73 \mathrm{~b}$ & $76 \mathrm{~b}$ \\
\hline 2 & $91 \mathrm{a}$ & $91 \mathrm{a}$ & $90 \mathrm{a}$ & $87 \mathrm{a}$ \\
\hline 3 & $84 \mathrm{a}$ & $77 \mathrm{~b}$ & $81 \mathrm{a}$ & $83 \mathrm{~b}$ \\
\hline 4 & $74 \mathrm{~b}$ & $77 \mathrm{~b}$ & $77 \mathrm{~b}$ & $67 \mathrm{c}$ \\
\hline 5 & $60 \mathrm{c}$ & $67 \mathrm{c}$ & $66 \mathrm{~b}$ & $67 \mathrm{~d}$ \\
\hline $\mathrm{F}$ & $16.44 *$ & $11.22 *$ & $5.28 *$ & $8.81 *$ \\
\hline CV\% & 7.20 & 6.41 & 9.93 & 8.12 \\
\hline
\end{tabular}

* Means followed by the same letter in the column do not differ by Scott-Knott's test at 5\% probability.

The accelerated aging test in the traditional procedure at $44^{\circ} \mathrm{C}$ for $24 \mathrm{~h}$ and with saline solution at $41{ }^{\circ} \mathrm{C}$ for $24 \mathrm{~h}$ provided the same emergency lot ranking, and the water content after aging varied by $2 \%$ between lots, fact that should be considered for the reliability of the results (MARCOS FILHO, 2015).

Therefore, the accelerated aging test is efficient to evaluate the physiological quality of chia seeds, being possible the reduction in the time of obtaining results when compared to the emergency test.

\section{Conclusions}

According to the results the electrical conductivity test on chia seeds should be performed with 100 seeds in $50 \mathrm{~mL}$ of distilled water, for four soaking hours at 25 or $30^{\circ} \mathrm{C}$.

The accelerated aging test should be performed at $44{ }^{\circ} \mathrm{C}$ for 24 hours by the traditional method or $41{ }^{\circ} \mathrm{C}$ for 24 hours using saturated $\mathrm{NaCl}$ solution. 


\section{References}

ALVES, C. Z.; GODOY, A. R.; CANDIDO, A. C. da; OLIVEIRA, N. C. de. Qualidade fisiológica de sementes de jiló pelo teste de envelhecimento acelerado. Ciência Rural, Santa Maria, v. 42, n. 1, p. 58-63, 2012. DOI: 10.1590/s0103-84782012000100010

ALVES, C. Z.; SÁ, M. E. Adequação da metodologia do teste de envelhecimento acelerado em sementes de rúcula. Semina: Ciência Agrárias, Londrina, v. 33, n. 6, p. 2789-2798, 2012. DOI: 10.5433/1679-0359.2012v33supl1p2789

ALVES, C. Z.; SÁ, M. E. Teste de condutividade elétrica na avaliação do vigor de sementes de rúcula. Revista Brasileira de Sementes, Londrina, v. 31, n. 1, p. 203-215, 2009. DOI: 10.1590/s0101-31222009000100023

BARBOSA, R. M.; COSTA, D. S.; SÁ, M. E. Envelhecimento acelerado em sementes de Alface. Ciência Rural, Santa Maria, v. 41, n. 11, p. 1899-1902, 2011. DOI: $10.1590 / \mathrm{s} 0103-84782011005000138$

BRASIL. Ministério da Agricultura, Pecuária e Abastecimento. Secretaria de Defesa Agropecuária. Regras para análise de sementes. Brasília: MAPA/ACS, 2009. 395 p.

GIVELBERG, A.; HOROWITZ, M.; POLJAKOFFMAYBER, A. Solute leakage from Solanum nigrum L. seeds exposed to high temperatures during imbibition. Journal of Experimental Botany, v. 35, n. 161, p. 17541763, 1984. DOI: $10.1093 / \mathrm{jxb} / 35.12 .1754$

HAMPTON, J. G.; TEKRONY, D. M. Handbook of vigour test methods. 3. ed. Zurich: ISTA, 1995. 117 p.

JIANHUA, Z.; McDONALD, M.B. The saturated salt accelerated aging test for small-seeded crops. Seed Science and Technology, Bassersdorf, v. 25, n. 1, p. 123131, 1996.

KULCZYNSKI, S. M.; MACHADO, E. C.; BELLÉ, C.; SANGIOGO, M.; KUHN, P. R.; SORATTO, R. P. Teste de Condutividade elétrica para avaliação da qualidade fisiológica de sementes de gergelim (Sesanun indicum L.). Revista Agrarian, Dourados, v. 7, n. 23, p. 72-81, 2014.

LOPES, R. R.; FRANKE, L. B. Teste de condutividade elétrica para avaliação da qualidade fisiológica de sementes de azevém (Lolium multiflorum L.). Revista Brasileira de Sementes, Londrina, v. 32, n. 1, p. 123-130, 2010. DOI: 10.1590/s0101-31222010000100014

LOPES, R. R.; FRANKE, L. B.; NUNES, F. S. Metodologia alternativa do teste de envelhecimento acelerado para sementes de azevém. Scientia Agraria, Curitiba, v. 10, n. 2, p. 89-94, 2009. DOI: 10.5380/rsa. v10i2.13572
MAGUIRE, J. D. Speeds of germination-aid selection and evaluation for seedling emergence and vigor. Crop Science, Madison, v. 2, n. 2, p. 176-177, 1962. DOI: 10.2135/cropsci1962.0011183x000200020033x

MARCOS FILHO, J. Fisiologia de sementes de plantas cultivadas. 2. ed. Londrina: ABRATES, 2015. 660 p.

MARCOS FILHO, J.; NOVEMBRE, A. D. L. C. Avaliação do potencial fisiológico de sementes de hortaliças. In: NASCIMENTO, W. M. (Ed.). Tecnologia de sementes de hortaliças. Brasília: Embrapa Hortaliças, 2009. p. 185-246.

MENDONÇA, E. A. F.; AZEVEDO, S. C. de, GUIMARAES, S. C.; ALBUQUERQUE, M. C. de F. Testes de vigor em sementes de algodoeiro herbáceo. Revista Brasileira de Sementes, Londrina, v. 30, n. 3, p. 1-9, 2008. DOI: 10.1590/s0101-31222008000300001

MENEZES, N. L.; GARCIA, D. M.; BAHRY, C. A.; MATTIONI, N. M. Teste de condutividade elétrica em sementes de aveia preta. Revista Brasileira de Sementes, Londrina, v. 29, n. 2, p. 138-142, 2007. DOI: 10.1590/ s0101-31222007000200019

MIGLIAVACCA, R. A.; SILVA, T. R. B. da; VASCONCELOS, A. L. S. de; MOURÃO FILHO, W.; BAPTISTELLA, J. L. C. O cultivo da chia no brasil: futuro e perspectivas. Journal of Agronomic Sciences, Umuarama, v. 3, p. 161-179, 2014. Número Especial.

NAKAGAWA, J. Testes de vigor baseados na avaliação das plântulas. In: KRZYZANOWSKI, F. C. (Ed.). Vigor de sementes: conceitos e testes. Londrina: ABRATES, 1999. p. 2.1-2.21.

PEREIRA, B. W. F.; SANTOS, P. C. das M.; LUZ, L. M. da; SILVA, D. B. da; MONTEIRO, T. M. A.; SILVA JÚNIOR, J. F. da; SILVA, C. S. da; FREITAS, J. M. $\mathrm{N}$. de. Teste de condutividade elétrica em sementes de alfavaca. Horticultura Brasileira, Brasília, v. 26, n. 2, p. 2021-2025, 2008.

RADKE, A. K.; REIS, B. B. dos; GEWHR, E.; ALMEIDA, A. da S.; TUNES, L. M. de; VILLELA, F. A. Alternativas metodológicas do teste de envelhecimento acelerado em sementes de coentro. Ciência Rural, Santa Maria, v. 46, n. 1, p. 95-99, 2016. DOI: 10.1590/0103$8478 \mathrm{cr} 20140188$

ROSSETTO, C. A. V.; MARCOS FILHO, J. Comparação entre os métodos de envelhecimento acelerado e de deterioração controlada para avaliação da qualidade fisiológica de sementes de soja. Scientia Agricola, Piracicaba, v. 52, p. 123-131, 1995. DOI: 10.1590/s010390161995000100020 
SORANA, C. K. P. M.; REGO, C. H. Q.; CARDOSO, F. B.; SILVA, T. R. B.; CÂNDIDO, A. C. S. ALVES, C. Z. Effects of temperature, substrate and luminosity conditions on chia seed germination. Caatinga. Mossoró, v. 32, n. 2, p. 411-418, 2019. DOI: 10.1590/1983-21252019v32n214rc

SOUZA, S. A.; NAKAGAWA, J.; MACHADO, C. G. Teste de envelhecimento acelerado em sementes de aveia preta. Revista Brasileira de Sementes, Londrina, v. 31 , n. 2 , p. $155-163$, 2009. DOI: 10.1590/s010131222009000200018

TORRES, S. B.; MEDEIROS, M. A. DE; TOSTA, M. S.; COSTA, G. M. M. Teste de condutividade elétrica em sementes de gergelim. Revista Brasileira de Sementes, Londrina, v. 31, n. 3, p. 70-77, 2009. DOI: 10.1590/ s0101-31222009000300008

TORRES, S. B.; PEREIRA, R. A. Condutividade elétrica em sementes de rúcula. Revista Brasileira de Sementes, Londrina, v. 32, n. 4, p. 58-70, 2010. DOI: 10.1590/ s0101-31222010000400007

TUNES L. M.; GADOTTI, G. I.; MUNIZ, M. F. B.; BARROS, A. C. S. A.; VILLELA, F. A. Accelerated aging to assess parsley seed vigor. Horticultura Brasileira, Brasília, v. 31, n. 3, p. 457-460, 2013. DOI: 10.1590/ s0102-05362013000300018
TUNES, L. M.; PEDROSO, D. C.; BARIBIERI, A. P. P.; CONCEIÇÃO, G. M.; ROETHING, E.; MUNIZ, M. F. B.; Barros, A. C. S. A. Envelhecimento acelerado modificado para sementes de coentro (Coriandrum sativum L.) e sua correlação com outros testes de vigor. Revista Brasileira de Biociências, Porto Alegre, v. 9, n. 1, p. 12-17, 2011.

TUNES, L. M.; TAVARES, L. C.; RUFINO, C. de A.; BARROS, A. C. S. A.; MUNIZ, M. F. B.; DUARTE, V. B. Envelhecimento acelerado em sementes de brócolis (Brassica oleracea L. var. italica Plenk). Bioscience Journal, Uberlândia, v. 28, n. 2, p. 173-179, 2012.

VIDIGAL, D. S.; LIMA, J. da S.; BHERING, M. C.; SANTOS, D. C. F. Teste de condutividade elétrica em sementes de pimenta. Revista Brasileira e Sementes, Londrina, v. 30 , n. 1, p. 168-174, 2008. DOI: 10.1590/ s0101-31222008000100021

VIEIRA, R. D. Teste de condutividade elétrica. In: VIEIRA, R. D.; CARVALHO, N. M. (Ed.). Testes de vigor em sementes. Jaboticabal: FUNEP, 1994. p. 103-32.

VIEIRA, R. D.; KRZYZANOWSKI, F. C. Teste de condutividade elétrica. In: KRZYZANOWSKI, F. C.; VIEIRA, R. D.; FRANÇA NETO, J. B. (Ed.). Vigor de sementes: conceitos e testes. Londrina. ABRATES, 1999. cap. 4, p. 1-26. 